\title{
STRATEGI PENGEMBANGAN USAHA RUMAH TANGGA ABON IKAN TUNA (Thunnus sp.) "BUNDA"
}

(Business Development Strategy Household Abon Ikan Tuna (Thunnus sp.) "BUNDA")

\author{
Andi Suci Anita \\ Program Studi Agribisnis Universitas Terbuka \\ Universitas Terbuka Banjarmasin, Jl. Sultan Adam No.128. Banjarmasin 70122 \\ Email : andisuci@ecampus.ut.ac.id
}

Article Submitted: 27-08-2020

Article Accepted : 14-09-2020

\begin{abstract}
Small and medium industries including household businesses really need to be developed into businesses that are able to develop independently into businesses to increase community income. Household businesses built by the community must of course take into account the potential that can support business continuity. The study was conducted on household businesses Abon Ikan Tuna "Bunda" in Lumpue Village, West Bacukki District, Parepare City. The purpose of this study is to determine the potential for household business development and formulate development strategies for household businesses. From the results of observations and interviews it can be concluded that this household business has the potential to be seen from the raw material resources, human resources, equipment resources, the environment and finance. Quantitative Analysis in this study uses the Process Hierarchy Analysis Method (AHP) so that the results obtained that an alternative sequence in business development in this household business that can be applied is the addition of marketing experts, strategies to increase product diversity development, increase production volume, conduct promotions broadly, adding equipment units, opening opportunities and expanding market networks and adding transportation equipment.
\end{abstract}

Keywords : Strategy, development, household business

\section{PENDAHULUAN}

Mengingat peranan sektor industri yang begitu penting dalam upaya peningkatan perekonomian Indonesia, maka pembinaan dan pengembangan pada sub sektor industri kecil sebagai salah satu bagian dari pembangunan industri nasional yang tidak boleh terlupakan. Selain itu, industri kecil juga dapat memberi manfaat sosial antara lain dapat menciptakan peluang usaha yang berperan dalam mobilisasi tabungan domestik, dan merupakan komplementer terhadap industri besar dan menengah karena industri kecil dapat menghasilkan produk yang telatif murah (Zuhal, 1987).

Komitmen pemerintah pada industri kecil nampak jelas, dikatakan bahwa industri kecil dan menengah termasuk usaha rumah tangga perlu lebih dibina menjadi usaha yang makin efisien dan mampu berkembang mandiri, meningkatkan pendapatan masyarakat dan membuka lapangan kerja (Suryana dkk, 1995).

Salah satu sektor pertanian yang dapat diandalkan adalah sektor perikanan. 
Hal ini disebabkan karena kondisi wilayah indonesia yang pada umumnya merupakan daerah maritim dengan garis pantai yang cukup panjang dan potensial. Pemanfaatan sumberdaya laut untuk perikanan merupakan hal hal yang amat penting sebagai sumber pangan dan komoditi perdagangan. (Hadiwiyoto, 1993).

Ikan sebagai komoditi utama di sub sektor perikanan merupakan salah satu bahan pangan yang kaya protein sehingga baik untuk dikomsumsi setiap harinya. Namun demikian, ikan merupakan komoditi yang cepat mengalami pembusukan (perishable food). Seiring dengan berkembangnya teknologi, ikan dimanfaatkan sebagai bahan baku produk olahan. Salah satu produk olahan yang cukup terkenal di masyarakat adalah abon ikan (Rizkia, 2015).

Potensi yang dimiliki oleh para usaha pembuat abon ikan tuna di Kelurahan Lumpue juga menjadi salah satu faktor yang mempengaruhi keberlangsungan usaha tersebut. Oleh karena itu, usaha rumah tangga abon ikan tuna dianggap mampu menjadi salah satu sumber pendapatan yang besar dalam meningkatkan perekonomian masyarakat khususnya para pengusaha abon ikan tuna di Kelurahan Lumpue, Kecamatan Bacukki Barat, Kota Parepare.

\section{METODE PENELITIAN}

Lokasi penelitian ini adalah di Kelurahan Lumpue, Kecamatan Bacukki Barat, Kota Parepare. Penentuan lokasi ini dilakukan secara sengaja (purposive) dengan pertimbangan bahwa usaha ini merupakan salah satu usaha rumah tangga yang cukup potensial namun belum berkembang secara optimal yang memproduksi abon ikan tuna. Waktu penelitian kurang lebih 3 bulan yakni bulan Juni sampai Agustus 2019.
Metode penelitian yang digunakan adalah metode penelitian kualitatif atau berusaha untuk menghasilkan data berupa gambaran atau lukisan secara nyata, sistematis dan apa adanya dari objek kajian. Dalam penelitian ini, metode kualitatif dilakukan pada usaha rumah tangga abon ikan tuna "Bunda" yang dilakukan dengan cara mewawancarai secara langsung pihak yang terkait dalam sistem produksi dan pemasaran abon ikan tuna.

\section{HASIL DAN PEMBAHASAN}

\section{Potensi Pengembangan Usaha Rumah Tangga Abon Ikan Tuna "Bunda" Sumberdaya Bahan Baku}

Lokasi penelitian ini dilakukan di Kelurahan Lumpue, Kota Parepare karena Kelurahan Lumpue merupakan salah satu Kelurahan di Kota Parepare yang memiliki sumberdaya hasil tangkapan ikan laut yang cukup menjanjikan untuk diusahakan dan dikembangkan. Selain itu, rata-rata pekerjaan penduduk yang ada di Kelurahan Lumpue adalah nelayan sehingga mudah untuk Usaha rumah tangga "Bunda" mendapatkan bahan baku utama yaitu ikan tuna.

Untuk mendapatkan bahan baku utama, Usaha rumah tangga "Bunda" membeli daging ikan tuna di PT. Philips Seafood Indonesia yang berada dekat dengan lokasi usaha tepatnya di Kelurahan Bojo Baru, Kabupaten Barru (Perbatasan antara Kota Parepare dan Kabupaten Barru) dengan harga Rp. 25.000,- per kilogram. Dengan membeli daging ikan tuna di PT. Philips Seafood, Usaha rumah tangga "Bunda" tidak perlu lagi memisahkan atau memotongmotong bagian-bagian tubuh ikan tuna sehingga pengerjaan abon ikan tuna lebih efisien. Menurut Ibu Syamsiah sebagai 
pemilik pemilik usaha bahwa dengan hanya membeli daging ikan tuna saja lebih murah dibandingkan dengan membeli ikan tuna yang utuh dengan harga Rp. 500.000,- per ekor dan selain itu tidak repot lagi untuk memisahkan bagian-bagian dari daging dan tulang ikan tuna tersebut karena kami hanya membeli dagingnya saja.

\section{Sumberdaya Manusia}

Adapun untuk mengetahui tenaga kerja yang bekerja pada sektor industi rumah tangga abon ikan tuna "Bunda" dapat dilihat pada table berikut :

Tabel 1. Tenaga Kerja Usaha Rumah Tangga Abon Ikan Tuna "Bunda” di Kelurahan Lumpue, Kecamatan Bacukki Barat, Kota Parepare, 2019.

\begin{tabular}{ccccccc}
\hline No. & Keterangan TK & $\begin{array}{l}\text { Umur } \\
\text { (Thn })\end{array}$ & Pendidikan & $\begin{array}{c}\text { Pengalaman } \\
\text { Bekerja }\end{array}$ & Jenis TK & Upah TK \\
\hline 1. & Ibu Syamsiah & 53 Tahun & SM A & 7 Tahun & $\begin{array}{c}\text { Pemilik Usaha } \\
\text { sekaligus } \\
\text { bagian } \\
\text { pemasaran } \\
\text { Proses }\end{array}$ & $\begin{array}{c}\text { Tanpa } \\
\text { Pemberian } \\
\text { Upah }\end{array}$ \\
2. & Ibu Dalle & 47 Tahun & SMP & 14 Tahun & $\begin{array}{c}\text { Produksi } \\
\text { Proses }\end{array}$ & 50 ribu \\
3. & Ibu Isakka & 37 Tahun & SMP & 5 Tahun & Produksi & 50 \\
\hline
\end{tabular}

Berdasarkan pada tabel diatas, terlihat beberapa faktor yang mempengaruhi tenaga kerja pada usaha rumah tangga abon ikan "Bunda" di Kelurahan Lumpue yaitu antara lain umur, pendidikan dan pengalaman bekerja dalam hal ini bekerja pada usaha rumah tangga yang mengolah ikan tuna menjadi abon. Jumlah tenaga kerja yang dimiliki oleh industri abon ikan tuna "Bunda" sebanyak dua orang pada proses produksi.

Berdasarkan umur diketahui bahwa tenaga kerja pada Usaha rumah tangga abon ikan "Bunda" berusia antara 37-53 tahun yang menunjukkan usia kedewasaan. Hal ini sesuai dengan data Badan Pusat Statistik dalam Maskur (2011) bahwa teori kependudukan menyatakan bahwa usia produktif seseorang berada diantara 15 sampai 56 tahun yang dilihat dari kemampuan berfikir dan bekerjanya. Dengan sifat dewasa dan mampu berfikir dengan matang sumberdaya manusia akan mampu bertahan dan bekerja keras untuk mencapai tujuannya serta menjaga konsistensi dalam beraktifitas dalam hal ini mengolah ikan tuna menjadi abon dan mengembangkan industri rumah tangga abon ikan tuna "Bunda" tersebut.

Berdasarkan pendidikan yang dimiliki oleh sumberdaya manusia yang bekerja pada sektor Usaha rumah tangga abon ikan tuna "Bunda" berpendidikan di bangku Sekolah Menengah Pertama (SMP) dan Sekolah Menengah Atas (SMA) yang menunjukkan bahwa pendidikan tidak berpengaruh besar terhadap kualitas produksi yang dihasilkan oleh suatu usaha khususnya pada industri rumah tangga abon ikan tuna "Bunda". Selain itu, pengalaman kerja yang dimiliki oleh sumberdaya manusia yang bekerja pada Usaha rumah tangga abon ikan tuna "Bunda" selama 5-14 tahun, yang menunjukkan waktu yang cukup lama berarti dalam bekerja mengolah ikan 
tuna menjadi abon juga sudah tidak diragukan lagi.

\section{Sumberdaya Peralatan}

Setiap peralatan yang digunakan pasti akan mengalami penyusutan sepanjang tahun dan nilainya akan berkurang sesuai dengan umur alat tersebut. Menghitung nilai penyusutan dapat dapat dilakukan dengan menggunakan metode garis lurus, yaitu besarnya nilai penyusutan sama dengan nilai atau harga barang dikali dengan presentase penyusustan, sedangkan presentase penyusutan dapat dihitung dengan membagi $100 \%$ dengan perkiraan masa produktif suatu barang. Adapun rumus yang digunakan untuk menghitung nilai penyusutan alat adalah sebagai berikut:

$$
\mathrm{PA}=\frac{H \arg a \text { Awal }-H \arg a \text { Akhir }}{\text { Lama Pemakaian }} x \sum \text { alat }
$$

\section{Keterangan: \\ $\mathrm{NP}=$ Nilai Penyusutan $(\mathrm{Rp})$ \\ LP = Lama Pemakaian (Tahun)}

Berdasarkan hasil wawancara, adapun sumberdaya peralatan yang dimiliki

oleh Usaha rumah tangga "Bunda" dapat dilihat pada tabel berikut:

Tabel 2. Jumlah, nilai dan jenis Peralatan yang digunakan dalam Proses Produksi

\begin{tabular}{|c|c|c|c|c|c|c|c|}
\hline No & $\begin{array}{c}\text { Jenis } \\
\text { Peralatan }\end{array}$ & $\begin{array}{l}\text { Jumlah } \\
\text { kebutuhan } \\
\text { (Unit) }\end{array}$ & $\begin{array}{c}\text { Harga Awal } \\
\text { (Rp/Unit) }\end{array}$ & $\begin{array}{c}\text { Nilai } \\
\text { (Jumlah } \\
\text { kebutuhan x } \\
\text { harga awal) }\end{array}$ & $\begin{array}{l}\text { Harga akhir } \\
\text { (Rp/unit) }\end{array}$ & $\begin{array}{c}\text { Umur } \\
\text { Ekonomis } \\
\text { (Thn) }\end{array}$ & $\begin{array}{c}\text { Nilai } \\
\text { penyusutan } \\
\text { (Rp/Thn) }\end{array}$ \\
\hline 1. & $\begin{array}{l}\text { Spinner } \\
\text { Alat }\end{array}$ & 1 & 1.500 .000 & 1.500 .000 & 700.000 & 10 & 800.000 \\
\hline 2 & $\begin{array}{l}\text { Penggiling } \\
\text { daging }\end{array}$ & 1 & 1.500 .000 & 1.500 .000 & 700.000 & 10 & 800.000 \\
\hline 3 & $\begin{array}{l}\text { Lemari } \\
\text { freezer }\end{array}$ & 1 & 2.000 .000 & 2.000 .000 & 1.000 .000 & 10 & 1.000 .000 \\
\hline 4 & Baskom & 2 & 15.000 & 30.000 & 5.000 & 3 & 10.000 \\
\hline 5 & $\begin{array}{l}\text { Kompor } \\
\text { gas }\end{array}$ & 2 & 250.000 & 500.000 & 100.000 & 5 & 150.000 \\
\hline 6 & Wajan & 2 & 50.000 & 100.000 & 20.000 & 3 & 30.000 \\
\hline 7 & Spatula & 2 & 10.000 & 20.000 & 5.000 & 2 & 5.000 \\
\hline 8 & Timbangan & 1 & 100.000 & 100.000 & 50.000 & 5 & 5.000 \\
\hline
\end{tabular}

Sumber :Data Primer Setelah Diolah, 2019.

Berdasarkan wawancara yang telah dilakukan dapat diketahui bahwa Usaha rumah tangga abon ikan tuna "Bunda" membeli peralatan-peralatan tersebut dari pedagang dan sebagian lainnya dibeli di pasar tradisional. Selain itu, Usaha rumah tangga abon ikan tuna "Bunda" juga mendapatkan bantuan peralatan dari Dinas Tenaga Kerja berupa spinner, alat penggiling dan freezer sehingga dalam proses produksi pengolahan ikan tuna menjadi abon pada usaha rumah tangga "Bunda" saat ini telah 
menggunakan peralatan yang cukup canggih dan moderen. Dengan menggunakan perelatan yang canggih dan moderen berarti jumlah produksi dari abon ikan tuna dapat meningkat sehingga dapat menguntungkan, karena dengan menggunakan perelatan yang canggih usaha rumah tangga Bunda dapat memanfaatkan sebuah peluang dalam berbisnis.

\section{Sumberdaya Finansial (Modal)}

Sumberdaya finansial biasanya identik dengan modal. Sumberdaya modal dapat diartikan sebagai modal atau untuk meningkatkan produksi. Selain itu, sumberdaya modal dapat juga diasumsikan sebagai harta yang dimiliki perusahaan, baik berupa uang tunai maupun barang-barang berharga lainnya. Pada Usaha rumah tangga abon ikan tuna "Bunda" yang dijalankan oleh Ibu Syamsiah menggunakan modal awal untuk usaha ini sebesar Rp. 25.000.000,- yang beliau dapatkan dari penjualan asset yang dimiliki. Ibu Syamsiah lebih memilih menjual asset yang dimilikinya daripada mengambil kredit bank ataupun lembaga-lembaga keuangan lainnya, karena tidak ada patokan dan batasan waktu untuk melunasi pinjaman atau modal yang digunakan.

\section{Proses Penentuan Kriteria dan Alternatif Strategi}

\section{Kriteria Produksi}

Produksi adalah suatu kegiatan untuk menciptakan atau menambah nilai guna suatu barang untuk dapat memenuhi suatu kebutuhan masyarakat dan memperoleh keuntungan dari kegiatan tersebut. Produksi merupakan salah satu faktor atau kreteria yang sangat berpengaruh dalam perkembangan pada usaha rumah tangga abon ikan tuna "Bunda". Kegiatan ini akan mempengaruhi dalam proses pembuatan hingga perbaikan kemasan produk.

\section{Alternatif Strategi Produksi}

Penentuan alternatif strategi dilakukan berdasarkan hasil diskusi, hasil kuisioner, dan berdasarkan masalah maupun hambatan yang terjadi pada usaha rumah tangga abon ikan tuna "Bunda" di Kelurahan Lumpue, Kota Parepare. Adapun urutan alternative strategi pasca panen yang perlu dikembangkan yaitu:

\section{1) Meningkatkan Volume Produksi}

Volume penjualan yang tinggi tentunya akan memberikan penghasilan yang tinggi pula bagi perusahaan. Tingginya penghasilan perusahaan tentunya dapat menjadi kontribusi sebagai penambahan modal untuk mengembangkan perusahaan yang telah ada. Dengan meningkatnya volume penjualan yang dilakukan oleh perusahan maka akan mempengaruhi tingkat pendapatan yang dimiliki oleh usaha rumah tangga abon ikan tuna "Bunda".

2) Penambahan Unit Peralatan Produksi

Penambahan Peralatan perusahaan akan mengakibatkan perusahaan semakin berkembang khususnya dalam meningkatkan skala produksi. Dengan bertambahnya peralatan maka usaha rumah tangga abon ikan tuna "Bunda" dapat lebih memperbesar kapasitas produksi. Diharapkan agar masingmasing peralatan pada usaha rumah tangga abon ikan tuna "Bunda" dapat bertambah menjadi dua unit.

3).Pengembangan Keanekaragaman Produk (Diversifikasi)

Dengan menjadikan produk lebih bervariasi perusahan dapat mengandalkan jenis lainnya (diversifikasi), jadi tidak hanya bergantung pada satu jenis produk yang dapat memenuhi selera dan kebutuhan 
konsumen, dapat memperluas pasar, member nilai tambah, dan lain sebagainya. Begitu juga deng usaha rumah tangga abon ikan tuna "Bunda", diharapkan dapat menambah variasi produk (diversifikasi) agar dapat meningkatkan volume penjualan.

\section{Kriteria Pemasaran}

Menurut Rangkuti (2009), pemasaran produk meliputi seluruh proses yang dimulai dari analisis pasar, mengantarkan produk ke pelanggan dan menerima umpan balik. Kegiatan pemasaran yang telah dilakukan oleh usaha rumah tangga abon ikan tuna "Bunda" dapat dikatakan belum optimal terkhusus pada kegiatan promosi. Selain itu, belum adanya upaya dalam peningkatan, mengembangkan maupun memperluas pangsa pasar. Jika kegiatan tersebut dapat likembangkan dengan baik, maka berdampak pada peningkatan minat konsumen terhadap produk abon ikan "Bunda".

\section{Alternatif Strategi Pemasaran}

Penentuan alternatif strategi dilakukan berdasarkan hasil diskusi, hasil kuisioner, dan berdasarkan masalah maupun hambatan yang terjadi pada usaha rumah tangga abon ikan tuna "Bunda" di Kelurahan Lumpue, Kota Parepare. Adapun urutan alternative strategi pasca panen yang perlu dikembangkan yaitu:

1) Melakukan Penambahan Alat
Transportasi
Dengan adanya alat transportasi khusus untuk perusahaan makan akan semakin memudahkan perusahaan menjalankan usahanya. Dengan memiliki kendaraan akan memudahnya perusahaan untuk memasarkan produknya ke wilayah-wilayah lain, memudahkan perusahaan untuk mempromosikan produknya. Dan produk akan dikenal banyak orang dan tetunya akan mempengaruhi permintaan konsumen dan menyebabkan pendapatan meningkat.

2) Melakukan Promosi Secara Luas

Kegiatan promosi perlu ditingkatkan agar produk lebih dikenal dimasyarakat luas. Promosi yang baik dapat meningkatkan pendapatan perusahaan. Saat ini proses promosi yang dilakukan oleh usaha rumah tangga abon ikan tuna "Bunda" hanya berjalan melalui mulut ke mulut. Untuk itu, perlu dilakukan kegiatan promosi melalui media cetak, elektronik, dan media sosial sehingga dapat diketahui dan dikenal oleh masyarakat.

3) Membuka Peluang dan Perluasan Jaringan Pasar

Dalam hal ini maksud dari membuka peluang dan perluasan jaringan pasar yang menguntungkan yaitu bekerjasama dari pihak pemerintah, LSM, Industri pengolahan, dan perguruan tinggi. Sehingga, pihak pemerintah setidaknya dapat memberikan dukungan seperti mengawasi jalannya proses pemasaran dan memberikan penyuluhan mengenai bagaimana cara mendapatkan sebuah peluang dalam pasar, besarnya permintaan produk abon ikan tuna, dan kualitas yang dibutuhkan oleh pasar. Selain itu, untuk memperluas jaringan pemasaran dapat dilakukan melalui program pengenalan produk abon ikan tuna "Bunda" kepada pihak luar Kota Parepare seperti kegiatan pameran maupun kegiatan lainnya. Melalui pengenalan produk diharapkan banyak pihak yang akan tahu mengenai produk abon ikan tuna "Bunda", sehingga pasar untuk produk tersebut akan semakin luas.

4) Penambahan Tenaga Kerja Ahli Bagian Pemasaran 
Tenaga kerja yang memadai dapat membantu kinerja perusahaan agar bisa berjalan dengan cepat. Pada usaha rumah tangga abon ikan "Bunda" hanya Ibu Syamsiah yang bertindak dalam proses pemasaran sehingga proses pemasaran tidak optimal. Dengan adanya tenaga kerja pemasaran yang cukup memadai dan ulet, maka tentu saja proses pemasaran pada usaha rumah tangga abon ikan tuna "Bunda" dapat berjalan dengan baik.

\section{Analisis AHP}

Strategi pengembangan pada usaha rumah tangga abon ikan tuna "Bunda" di

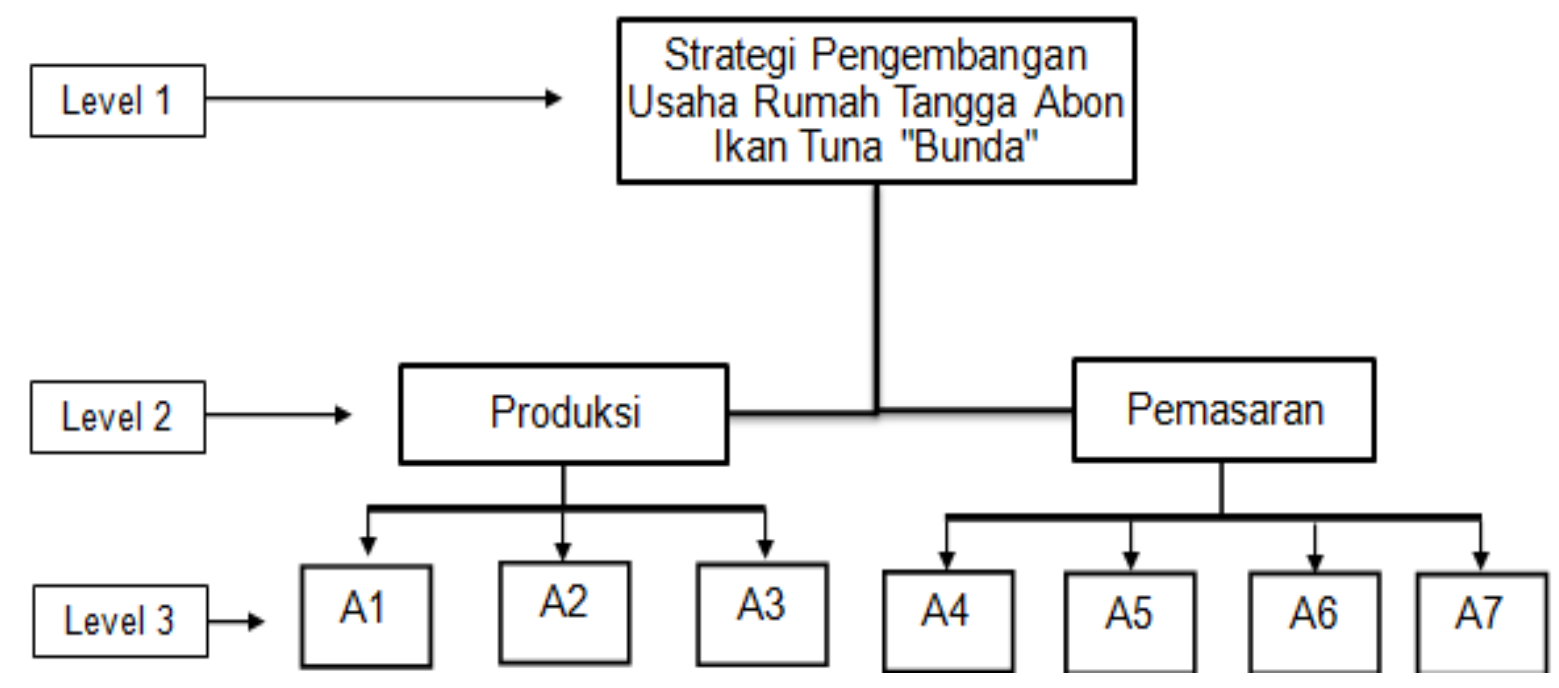

Gambar 1. Hierarki Pengembangan Usaha Abon Ikan Tuna "Bunda"

Keterangan :

Level 1 : Tujuan (Pengembangan Usaha Abon Ikan Tuna "Bunda")

Level 2 : Kriteria

Level 3 : Alternatif Strategi Pengembangan

A1 : Meningkatkan volume produksi

A2 : Menambah unit peralatan

A3 : Pengembangan keanekaragaman produk (Diversifikasi)

A4 : Melakukan penambahan alat transportasi

A5 : Melakukan promosi secara luas

A6 : Membuka peluang dan perluasan jaringan

A7 : Penambahan tenaga kerja ahli bidang pemasaran

Kelurahan Lumpue, Kecamatan Bacukki Barat, Kota Parepare dirumuskan menggunakan metode AHP (Analysis Hierarchy Process). Tujuan alternatif dan kriteria yang digunakan dalam AHP dirumuskan dari hasil survei dan diskusi dengan responden terhadap pengembangan pada usaha rumah tangga abon ikan tuna "Bunda". 


\section{Penyusunan Hierarki}

Kriteria dan alternatif yang telah ditentukan kemudian disusun menjadi sebuah hierarki pengembangan usaha rumah tangga abon ikan tuna "Bunda" di Kelurahan Lumpue. Berikut struktur hierarki pengembangan pada usaha rumah tangga abon ikan tuna "Bunda" di Kelurahan Lumpue, Kecamatan Bacukki Barat, Kota Parepare :

\section{Kriteria Pengembangan Usaha}

Sebagai prioritas pengembangan usaha rumah tangga abon ikan tuna "Bunda", dilakukan dengan cara memilih kriteria-kriteria yang telah ditentukan yaitu aspek produksi, dan aspek pemasaran. Dari masing-masing aspek tersebut yang menjadi kriteria terdapat alternatif sebagai langkah pengembangan usaha abon ikan tuna "Bunda" yang dipilih dari yang paling prioritas.

Berdasarkan hasil responden menunjukkan bahwa kriteria strategi pengembangan pemasaran dengan nilai bobot 0,667 merupakan kriteria paling penting yang perlu diperhatikan dalam strategi pengembangan pada usaha rumah tangga abon ikan tuna "Bunda" di Kelurahan Lumpue, Kecamatan Bacukki Barat, Kota Parepare dan berikut adalah kriteria strategi pengembangan pasca panen dengan nilai bobot 0,333 .

Tabel 3. Kriteria Pengembangan Usaha, Alternatif Kriteria Pemasaran Abon Ikan Tuna "Bunda"

\begin{tabular}{clc}
\hline No. & \multicolumn{1}{c}{ Kriteria } & Nilai Bobot \\
\hline & A. Pengembagan Usaha & 0.333 \\
1. & Strategi Pengembangan Produksi & 0.667 \\
\hline 2. & Strategi Pengembangan Pemasaran & \multicolumn{1}{c}{ Inconsistency Ratio = 0.0 } \\
\hline \multicolumn{2}{c}{ B. Alternatif Kriteria Pemasaran } \\
3 & Melakukan penambahan alat transportasi & 0.104 \\
4 & Melakukan promosi secara luas & 0.226 \\
5 & Membuka peluang dan perluasan jaringan & 0,159 \\
6 & Penambahan tenaga kerja ahli bidang & 0,510 \\
& pemasaran & \\
\hline & $\quad$ Inconsistency Ratio $=0.05$ \\
7 & Meningkatkan volume produksi & 0.311 \\
8 & Menambah unit peralatan & 0.196 \\
9 & Pengembangan keanekaragaman produk & 0.493 \\
\hline & (diversifikasi)
\end{tabular}

\section{Sumber : Tabulasi Data Primer.}

Hasil olah data AHP digunakan untuk menentukan strategi pengembangan yang menjadi prioritas, memberikan informasi mengenai beberapa strategi yang perlu diperbaiki atau dikembangkan untuk pengembangan pada usaha rumah tangga abon ikan tuna "Bunda" di Kelurahan Lumpue, Kecamatan Bacukki Barat, Kota Parepare. Kemudian, dari strategistrategi yang menjadi kriteria dari yang paling prioritas secara berurutan akan 
diuraikan lebih lanjut dalam alternatif masing-masing kriteria.

\section{Kriteria Pemasaran}

Strategi pemasaran menjadi strategi terpenting dan paling diprioritaskan untuk dilakukan dalam strategi pengembangan pada usaha rumah tangga abon ikan tuna "Bunda" di Kelurahan Lumpue, Kecamatan Bacukki Barat, Kota Parepare. Dalam strategi pemasaran terdapat dua alternatif yang menjadi acuan sebagai upaya pengembangan usaha diantaranya adalah menambah alat transportasi, melakukan promosi baik melalui media cetak, elektronik, dan media sosial, membuka peluang pasar dengan melakukan kerja sama dari pihak pemerintah, LSM, Industri pengolahan, perbankan dan perguruan tinggi, serta penembahan tenaga ahli pada bidang pemasaran. Berdasarkan hasil olah data diketahui alternatif yang menjadi prioritas dalam strategi pemasaran untuk mengembangkan pada usaha rumah tangga abon ikan tuna "Bunda" di Kelurahan Lumpue, Kecamatan Bacukki Barat, Kota Parepare, sebagai berikut :

Dari tabel diatas dapat diketahui bahwa melakukan penambahan tenaga kerja ahli bidang pemasaran yang paling diprioritaskan dalam pengembangan abon ikan tuna "Bunda" dari strategi pemasaran dengan persentase prioritas sebesar $51 \%$. Melakukan promosi secara luas adalah alternatif kedua dengan nilai persentase 22,6\%. Membuka peluang dan perluasan jaringan menjadi alternatif ke tiga dengan nilai persentase $15,9 \%$. Sedangkan yang menjadi alternatif terakhir dalam kriteria pemasaran untuk pengembangan pada usaha rumah tangga abon ikan tuna "Bunda" di Kelurahan Lumpue, Kecamatan Bacukki Barat, Kota Parepare adalah melakukan penambahan alat transportasi dengan persentase prioritas sebesar 10,4\%. Dari hasil olah data AHP untuk alternatif kriteria pemasaran telah didapat urutan alternatif strategi yang perlu dilakukan untuk pengembangan usaha di Kecamatan Camba, Kabupaten Maros dari aspek pemasaran.

\section{Kriteria Produksi}

Kriteria produksi memiliki tiga alternatif diantaranya meningkatkan volume produksi, menambah unit peraratan, dan mengembangkan keanekaragaman produk (diversifikasi). Berdasarkan hasil olah data diketahui alternatif yang menjadi prioritas dalam strategi produksi untuk mengembangkan pada usaha rumah tangga abon ikan tuna "Bunda" di Kelurahan Lumpue, Kecamatan Bacukki Barat, Kota Parepare, sebagai berikut :

Tabel diatas menunjukkan bahwa pengembangan keanekaragaman produk (diversifikasi) dengan persentase prioritas sebesar 49,3\% menjadi alternatif prioritas utama dalam aspek produksi sebagai upaya pengembangan pada usaha rumah tangga abon ikan tuna "Bunda" di Kelurahan Lumpue, Kecamatan Bacukki Barat, Kota Parepare. Alternatif prioritas kedua dengan persentase nilai sebesar $31,1 \%$ adalah meningkatkan volume produksi. Sebagai prioritas terakhir dalam aspek produksi adalah menamba unit peralatan dengan persentase prioritas sebesar $19,6 \%$.

\section{Urutan Alternatif Strategi Pengembangan}

Hasil analisis secara keseluruhan (overall) terlihat pada tabel 12 yang menunjukan keseluruhan nilai bobot aspek dalam strategi pengembangan pada usaha rumah tangga abon ikan tuna "Bunda" di Kelurahan Lumpue, Kecamatan Bacukki Barat, Kota Parepare dengan analisis 
Analysis Hierarchy Process (AHP).

Berdasarkan tabel tersebut dapat diketahui bahwa aspek yang terpilih dalam pengembangan pada usaha rumah tangga abon ikan tuna "Bunda" di Kelurahan Lumpue, Kecamatan Bacukki Barat, Kota Parepare adalah melakukan penambahan tenaga kerja ahli pemasaran, keaneka ragaman produk, peningkatan volume produksi, promosi baik melalui media cetak, elektronik, dan media sosial, menambah unit peralatan dan membuka peluang dan perluasan jaringan.

Tabel 4. Urutan Alternatif Strategi Pengembangan pada usaha rumah tangga abon ikan tuna "Bunda" di Kelurahan Lumpue, Kecamatan Bacukki Barat, Kota Parepare dari yang Paling Prioritas.

\begin{tabular}{llll}
\hline No & \multicolumn{1}{c}{ Alternatif } & \multicolumn{1}{c}{ Nilai Bobot } & \multicolumn{1}{c}{ Kriteria } \\
\hline 1. & Penambahan tenaga kerja ahli pemasaran & 0.510 & Aspek Pemasaran \\
2. & $\begin{array}{l}\text { Pengembangan keanekaragaman produk } \\
\text { (Diversifikasi) }\end{array}$ & 0.493 & $\begin{array}{l}\text { Aspek } \\
\text { Produksi }\end{array}$ \\
3. & Meningkatkan volume produksi & 0.311 & Aspek Produksi \\
4. & Melakukan promosi & 0,226 & Aspek Pemasaran \\
& secara luas & 0.196 & Aspek Produksi \\
5. & Menambah unit peralatan & Aspek Pemasaran \\
6. & Membuka peluang dan perluasan jaringan & 0.159 & Aspek Pemasaran \\
7. & Melakukan penambahan alat transportasi & 0.104 & \\
\hline
\end{tabular}
Sumber : Tabulasi Data Primer.

\section{KESIMPULAN DAN SARAN}

\section{Kesimpulan}

Dari hasil data menggunakan proses hirarki (AHP) dapat diketahui bahwa strategi pengembangan pada usaha rumah tangga abon ikan tuna "Bunda" di Kelurahan Lumpue, Kecamatan Bacukki Barat, Kota Parepare terdiri dari kriteria strategi pengembangan pemasaran dengan nilai bobot (0.667) yang merupakan prioritas pertama, dan kriteria strategi pengembangan produksi dengan nilai bobot $(0.333)$ menjadi prioritas kedua dalam pengembangan pada usaha rumah tangga abon ikan tuna "Bunda". Adapun urutan alternatif dalam pengembangan usaha pada usaha rumah tangga abon ikan tuna "Bunda" yang dapat diterapkan yaitu penambahan tenaga kerja ahli bidang pemasaran dengan prioritas 0.510, kemudian strategi penambahan pengembangan keanekaragaman produk (diversifikasi) dengan prioritas 0.493, strategi meningkatkan volume produksidengan prioritas 0.311 , strategi melakukan promosi secara luas dengan prioritas 0.226, strategi menambah unit peralatan dengan prioritas sebesar 0.196, strategi membuka peluang dan perluasan jaringan pasar dengan prioritas 0.159 , dan strategi melakukan penambahan alat transportasi dengan prioritas 0.104 .

\section{Saran}

Sebaiknya dilakukan upaya peningkatan pengetahuan dan keterampilan tenaga kerja. Dalam pelaksanaannya dibutuhkan dukungan dan peran dari pemerintah maupun semua pihak yang terkait berupa memberikan fasilitas dalam peningkatan kapasitas untuk dapat meningkatkan keterampilan tenaga kerja pada usaha rumah tangga abon ikan tuna "Bunda". Pemerintah disarankan untuk 
melakukan pengawasan mulai dari proses awal kegiatan produksi hingga tahap pemasaran. Dari pihak swasta disarankan dapat memberikan dukungan berupa hubungan mitra usaha yang berkelanjutan, sehingga dapat membagi informasi terbaru dan mendukung pengembangan usaha abon ikan tuna "Bunda".

\section{DAFTAR PUSTAKA}

Afrianto, E dan Liviawaty, E. 1991. Pengawetan dan Pengolahan Ikan. Yogyakarta: Penerbit Kanisius.

Afriyanto dan Liviawati. 1989. Pengawetan dan Pengolahan Ikan. Penerbit Kanisius, Yogyakarta.

Ahmad Subagyo, 2008. Studi Kelayakan. PT. Elex Media Komputindo: Jakarta.

Assauri, Sofjan. 2011. Manajemen Pemasaran. PT. Rajagrafindo Persada: Jakarta.

Badan Pusat Statistik Sulawesi Selatan, 2016. Provinsi Sulawesi Selatan Dalam Angka (Sulawesi Selatan Province In Figure). Badan Pusat Statistik Sulawesi Selatan.

Choir. 2010. Transaksi Proses Produksi. www.bakpia25.com. Diakses pada tanggal 20 September 2019.

Fadillah, M. 2008. Studi Pengembangan Usaha Gula Merah Tebu. http://cyntia-

unipdu.kompasiana.com/. Diakses pada tanggal 17 September 2019.

FAO (Food and Agriculture Organization of the United Nation). 1983. An Annotated and Illustrated Catalogue of Tunas, Mackerel, Bonitos, Untied Nations Development Programme Food and Agriculture Organization of the United Nations and Related Species Know to Date. Rome: FAO .

Fitz-enz, Jac dan Davidson, Barbara. 2001, How to Meansure Human Resources Management. Kencana Prenada Media Group: Jakarta.

Flick GJ, Martin RE. 1990. The Seafood Industry. New York: Van Nostrand Reinhold.

Gasperz, Vincent, 2005. Production Planning and Inventory Control. PT. Gramedia Pustaka Utama: Jakarta.

Hadiwiyoto, M.S.P., 1994. Manajemen Sumberdaya Manusia (dasar-Dasar dan KunciKeberhasilan). CV. Masagung, Jakarta.

Hariandja, Marihot Tua Efendi. 2017. Manajemen Sumber Daya Manusia. Jakarta: PT. Gramedia Widiasarana.

Husnul, Marhawati Mappatoba, Rustam Abd. Rauf, 2013. Strategi Pengembangan Usaha Abon Ikan Melalui Pendekatan Marketing Mix. Fakultas Pertanian. Universitas Tadulako.

Kotler 09, Philip, dan gary amstrong. 2009. Manajemen pemasaran jilid 1 edisi ketiga belas, terjemahan bob sabran, MM. Jakarta: penerbit erlangga.

Leksono, T dan Syahrul. 2001. Studi Mutu Dan Penerimaan Konsumen Terhadap Abon Ikan. Jurnal Natur Indonesia III (2): 178- 184.

Mulyadi, 2009. Manajemen Sumber Daya Manusia. PT. Gramedia Pustaka Utama: Jakarta.

Neneng, 2000. Dalam Skripsi (Prospek Pengembangan Usaha Pembuatan 
Nata De Coco). Universitas Hasanuddin.

Pambudy, 2001. Pengertian Sumber Daya Peralatan. Diakses melalui www.id.shvoong.com. Pada tanggal 29 September 2019.

Predita MA, 3013. Perkembangan Industri Kecil di Indonesia. http://lib.geo.ugm.ac.id/ojs/index.php /jbi/article/viewFile/79/77. Diakses pada tanggal 14 September 2019.

Rangkuti, fredy. 2009. Strategi Promosi Yang Kreatif. Jakarta: Gramedia Pustaka Utama.

Ratih, 2011. Analisis dan perbaikan sistem kerja berdasarkan metode studi gerak dan waktu pada proses produksi biskuit longs tick. IPB.

Rini, 2008. Pengembangan Usaha Ikan Abon di Kub Hurib Mandiri. Kecamatan Cisolok Kabupaten Suka Bumi [skipsi]. Bogor. Fakultas Pertanian. Institut Pertanian Bogor.

Rizkia, 2015. Strategi Pengembangan Abon Ikan. Studi Eksperensial pada Rumah Abon Ikan di Kota Bandung. Perikanan Kelautan. Universitas Padjajaran.
Robertson, G.L. 2006. Food Packaging: Principles and Practice, Marcel Dekker Inc. New York, pp 3-4.

Ronny Martha, 2006. Analisa Kelayakan Industri Fillet Ikan Patin Beku. Fakultas Teknologi Pertanian. Institut Pertanian Bogor.

Saanin H. 1984. Taksonomi dan Kunci Iden tifikasi Ikan I dan II. Jakarta: Bina Cipta.

Sartono, 2001. Sumber Daya Finansial. http://binaukm.com/. Dalam www.google.com. Diakses pada tanggal 17 September 2019.

Satori. 2009. Metodologi Penelitian Kualitatif. Bandung: Alfabeta.

Sexton, Don. 2007. Marketing 101. PT. Bhuana Ilmu Populer Kelompok Gramedia: Jakarta.

Suryana, A. Syamsuddin, Imelda Rosellawati, Idris Sumase, Agus Ashari, Eymal B. Demmalino, Suardi Bakri, Rusli M.Rukka. 1995. Mulai Dengan Usaha Kecil, Merintis Karir Kewirausahaan Anda. PUKTI Hasanuddin University Press, Makassar.

Zuhal, R.M., 1987. Resep-resep industri. Penerbit CV. Bintang Pelajar. 